\title{
PENGARUH ARUS KAS BEBAS, HUTANG DAN LABA TERHADAP DIVIDEN PADA PERUSAHAAN MANUFAKTUR YANG TERCATAT DI BURSA EFEK INDONESIA TAHUN 2012-2014
}

\author{
Lidya Ayu Purnamasari \\ Department of Management \\ E-mail: lidya.ayupurnamasari@yahoo.co.id
}

\begin{abstract}
The purpose of this research is to know and analyze the effect of variable free cash flow (FCF), debt (DAR) and earnings (EPS) of dividends (DPR), and determine which variables are most effect on the dividend. This type of research is explanatory research with quantitative approach and using multiple regression analysis with a sample of manufacturing companies listed in Indonesia Stock Exchange that cash dividends for three years, have complete data, and does not have a negative net income during the years 2012-2014. Based on the results of the research indicated that the variable free cash flow $(F C F)$, debt (DAR) and earnings (EPS) significantly affects the dividend (DPR), which is reinforced by $F$ test and $t$ test. The results of the f test (simultaneous) indicate that third variable indepen (free cash flow, debt and profit) together affect dividends significantly. The results of the $t$ test (partial) indicates that the variable free cash flow positive effect is not significantly to dividends. Variable debt negative effect is not significanly to dividend and variable profit significant positive effect on the dividend. The variables that most influence on dividends are variable profit.
\end{abstract}

Keywords: Dividend, Free Cash Flow, Debt, Profit

\section{PENDAHULUAN}

Dewasa ini perusahaan dihadapkan pada suatu kondisi persaingan yang ketat terutama perusahaan go public yang menghadapi persaingan tidak hanya dalam satu sektor industri saja melainkan antar sektor industri.Banyak perusahaan yang harus memutar otak dan berusaha untuk dapat menjalankan roda bisnisnya. Salah satu perusahaan itu adalah perusahaan manufaktur.

Pelemahan rupiah otomatis menjadi penghambat performa emiten yang mempunyai utang dalam dollar
AS dan berpotensi menggerus laba perusahaan. Pembagian dividen perusahaan manufaktur mengalami perubahan setiap tahunnya, tahun 2012 berjumlah 56 perusahaan, tahun 2013 berjumlah 62 perusahaan dan tahun 2014 mengalami penurunan secara drastis yaitu hanya 34 perusahaan manufaktur yang membagikan dividen (www.idx.co.id).

Berdasarkan uraian diatas, terdapat data empiris mengenai variabel - variabel yang digunakan dalam penelitian ini dapat dilihat pada tabel 1 sebagai berikut: 
Tabel 1. Harga Saham

\begin{tabular}{ccccc}
\hline Tahun & Kas $(\mathrm{Rp})$ & Hutang $(\mathrm{Rp})$ & Laba $(\mathrm{Rp})$ & Dividen (Rp) \\
\hline 2012 & 78.163 .883 & 408.350 .252 & 76.377 .899 & 29.916 .765 \\
2013 & 95.897 .246 & 511.884 .201 & 78.417 .665 & 41.815 .600 \\
2014 & 98.743 .890 & 559.263 .366 & 74.838 .344 & 30.884 .433 \\
\hline
\end{tabular}

Pada Tabel 1 menunjukkan jumlah kas, hutang, laba dan dividen pada perusahaan manufaktur tahun 2012-2014. Jumlah kas perusahaan manufaktur mengalami peningkatan berturut-turut dari tahun 2012 ke tahun 2014. Namun, jumlah dividen per lembar saham yang dibagikan dari tahun 2012 ke tahun 2013 mengalami peningkatan yang cukup signifikan, sedangkan tahun 2014 jumlah dividen mengalami penurunan yang cukup signifikan. Hal ini menandakan bahwa kenaikan jumlah kas pada tahun 2014 tidak diikuti dengan kenaikan jumlah dividen tahun 2014 yang dibagikan oleh perusahaan ke pemegang saham. Jumlah hutang mengalami peningkatan berturut-turut dari tahun 2012 hingga tahun 2014, sedangkan jumlah dividen mengalami peningkatan dari tahun 2012 ke tahun 2013 dan tahun 2014 mengalami penurunan. Jumlah laba tahun 2012 hingga tahun 2014 mengalami fluktuasi dimana pada tahun 2012 ke tahun 2013 laba mengalami peningkatan yang cukup stabil.

Sedangkan tahun 2013 ke tahun 2014 laba mengalami penurunan. Jumlah dividen pada tahun 2012 ke 2013 mengalami peningkatan yang cukup signifikan, sedangkan pada tahun 2014 dividen mengalami penurunan yang cukup signifikan.
Hal ini menandakan pembagian dividen perusahaan tidak hanya dilihat dari faktor besar kecilnya laba yang diterima perusahaan, perusahaan bisa membayar dividen lebih rendah karena laba digunakan untuk meningkatkan laba ditahan.

Berdasarkan latar belakang diatas, maka perumusan masalah dalam penelitian ini dapat dirumuskan sebagai berikut: Apakah variabel arus kas bebas, hutang dan laba berpengaruh signifikan terhadap dividen pada perusahaan manufaktur yang tercatat di Bursa Efek Indonesia tahun 20122014. Diantara variabel arus kas bebas, hutang dan laba manakah yang paling berpengaruh terhadap dividen pada perusahaan manufaktur yang tercatat di Bursa Efek Indonesia tahun 2012-2014.

Adapun tujuan dari peneliti adalah: Untuk mengetahui dan menganalisis pengaruh variabel arus kas bebas, hutang dan laba terhadap dividen. Untuk mengetahui dan menganalisis variabel yang paling berpengaruh terhadap dividen pada perusahaan manufaktur yang tercatat di Bursa Efek Indonesia tahun 20122014.

\section{TINJAUAN PUSTAKA}

(Brigham, 2012:210) dividen merupakan laba perusahaan yang 
didistribusikan kepada para pemegang saham dalam bentuk kas atau saham. (Ross et al, 2009:208), menyatakan definisi dividen adalah suatu bentuk pembayaran yang dilakukan oleh perusahaan kepada para pemiliknya, baik dalam bentuk kas maupun saham.

Menurut (Gitman, 2000:540) memberikan definisi kebijakan dividen sebagai suatu perencanaan tindakan perusahaan yang harus dituruti ketika keputusan dividen harus dibuat. (Lee dan Finerty, 1990 dalam Rosdini, 2009) mengartikan kebijakan dividen sebagai suatu keputusan perusahaan apakah akan membagikan earnings yang dihasilkan kepada para pemegang saham atau akan menahan earnings untuk kegiatan reinvestasi dalam perusahaan.

Agency Theory dikemukakan oleh (Jensen and Meckling,1976 dalam Suhadak dan Ari, 2011:105) dengan prinsip dan pemikiran dasar yang menyatakan adanya pemisahan fungsi manajerial dan kepemilikan perusahaan.

Ketidakseimbangan informasi antara manajer dan pemegang saham ini disebut sebagai asimetri

informasi. Asimetri informasi ini dapat membuat manajer mungkin tidak selalu bertindak demi kepentingan investor. Salah satu tindakan yang dimaksud adalah ketika manajer menggunakan arus kas bebas.

(Brigham, 2012:109), Free Cash Flow adalah arus kas yang benarbenar tersedia untuk dibayarkan kepada investor (pemegang saham dan pemilik utang) setelah perusahaan melakukan investasi dalam aset tetap, produk baru, dan modal kerja yang dibutuhkan untuk mempertahankan operasi yang sedang berjalan. Apabila tidak dibagikan sebagai dividen, dana bebas ini dapat digunakan sebagai penambah modal untuk aktivitas perusahaan seperti ekspansi, akuisisi, pembayaran utang, dan aktivitas yang berorientasi pada pertumbuhan perusahaan.

Hutang adalah kewajiban perusahaan yang memerlukan pembayaran kas pada waktu yang telah ditentukan. Peningkatan hutang akan mempengaruhi besar kecilnya laba bersih yang tersedia bagi pemegang saham termasuk dividen yang akan diterima, semakin tinggi hutang maka kemampuan perusahaan untuk membagikan dividen kepada pemegang saham akan semakin kecil. Semakin banyak hutang yang harus dibayar, semakin besar dana yang harus disediakan sehingga akan mengurangi jumlah dividen yang akan dibayarkan pada pemegang saham (Kieso, 2002:362).

Laba merupakan keuntungan yang dimiliki oleh perusahaan yang berasal dari pendapatan dikurangi dengan biaya-biaya. Laba inilah yang menentukan apakah perusahaan akan membagikan dividen tunai atau dividen saham. Suatu perusahaan yang mempunyai laba stabil sering dapat memperkirakan berapa besar laba di masa yang akan datang. Perusahaan seperti ini cenderung membayarkan dividen dengan persentase yang lebih tinggi daripada perusahaan yang labanya berfluktuasi. Dividen yang lebih rendah akan lebih mudah untuk dibayar apabila laba menurun pada masa yang akan datang (Copeland, 2010:217). 
Untuk mempermudah dalam menjelaskan kerangka pikir. Besar kecilnya jumlah dividen yang akan dibagikan oleh perusahaan kepada para pemegang saham dapat dipengaruhi oleh berbagai macam faktor. Penelitian ini akan meneliti tentang faktor-faktor yang bersumber dari laporan keuangan perusahaan. Variabel Arus Kas Bebas $\left(X_{1}\right)$, Hutang $\left(X_{2}\right)$, Laba $\left(X_{3}\right)$ yang diduga mempengaruhi keputusan pembagian Dividen (Y).

Adapun bagan kerangka pikir penelitian ini adalah:

Adapun hipotesis dalam penelitian ini yaitu: Variabel Arus Kas Bebas, Hutang dan Laba berpengaruh signifikan terhadap dividen pada perusahaan manufaktur yang tercatat di Bursa Efek Indonesia periode 2012-2014.

Variabel laba yang paling berpengaruh terhadap dividen pada perusahaan manufaktur yang tercatat di Bursa Efek Indonesia tahun 20122014.

\section{METODE PENELITIAN}

Jenis penelitian ini adalah penelitian eksplanatory (explanative research) dengan pendekatan kuantitatif. Sifat penelitian ini adalah replikasi dan pengembangan, yaitu suatu penelitian pengulangan dari penelitian-penelitian terdahulu yang serupa namn dengan sampel, variabel dan periode yang berbeda.

Variabel Dependen yang digunakan dalam penelitian ini adalah variabel dividen, dimana dividen adalah bentuk pembayaran yang dilakukan oleh perusahaan kepada para pemiliknya,baik dalam bentuk kas maupun saham. Dividen diukur dengan dividend payout ratio (DPR).
Variabel Independen yang digunakan dalam penelitian adalah Arus Kas Bebas $\left(X_{1}\right)$,merupakan kas perusahaan yang dapat didistribusikan kepada kreditor atau pemegang saham yang tidak digunakan untuk modal kerja atau investasi pada aset tetap.

Hutang $\left(X_{1}\right)$, merupakan kewajiban perusahaan yang memerlukan pembayaran kas pada waktu yang telah ditentukan. Hutang diukur dengan Debt to Total Assets Ratio (DAR).

Laba $\left(X_{3}\right), \quad$ merupakan keuntungan yang dimiliki oleh perusahaan yang berasal dari pendapatan dikurangi dengan biayabiaya. Laba diukur dengan Earning Per Share (EPS).

Populasi yang digunakan dalam penelitian ini adalah 137 perusahaan manufaktur yang tercatat di Bursa Efek Indonesia pada periode 2012-2014. Metode pengambilan sampel adalah metode purposive sampling.

Jenis data yang digunakan dalam penelitian ini menggunakan data kuantitatif. Sumber data yang digunakan dalam penelitian ini adalah data sekunder. Data sekunder diperoleh dari situs internetwww.idx.co.id, Bursa Efek Indonesia (BEI), Indonesian Capital Market Directory (ICMD) dan Annual Report perusahaan manufaktur 2012-2014.

\section{HASIL PENELITIAN DAN PEMBAHASAN}

Berdasarkan kriteria dari pengambilan sampel maka diperoleh 21 perusahaan manufaktur yang tercatat di Bursa Efek Indonesia. 
Hasil persamaan regresi berganda maka dapat dirumuskan suatu persamaan regresi berganda sebagai berikut:

$\mathrm{Y}=8,776+1,050 \mathrm{X}_{1}-1,106 \mathrm{X}_{2}+$ $1,156 X_{3}$

$\mathrm{a}=8,776$, artinya jika semua variabel bebas tidak ada, maka nilai variabel terikat sebesar 8,776.

$\mathrm{b}_{1}=1,050$, koefisien regresi ini menunjukkan bahwa apabila variabel bebas lain bernilai tetap dan arus kas bebas mengalami kenaikan sebesar Rp. 1, maka dividen akan mengalami kenaikan sebesar 1,050. Dapat dilihat bahwa koefisien yang diperoleh bernilai positif, jadi apabila terjadi peningkatan pada $\left(\mathrm{X}_{1}\right)$, maka $\mathrm{Y}$ akan meningkat dan sebaliknya.

$\mathrm{b}_{2}=-1,106$, koefisien regresi ini menunjukkan bahwa apabila variabel bebas lain bernilai tetap dan hutang mengalami kenaikan sebesar $1 \%$, maka dividen akan mengalami penurunan sebesar 1,106. Dapat dilihat bahwa koefisien yang diperoleh bernilai negatif, jadi apabila terjadi peningkatan pada $\left(\mathrm{X}_{2}\right)$, maka $\mathrm{Y}$ akan menurun dan sebaliknya.

$\mathrm{b}_{3}=1,156$, koefisien regresi ini menunjukkan bahwa apabila variabel lain bernilai tetap dan laba mengalami kenaikan Rp. 1, maka dividen akan mengalami kenaikan sebesar 1,156. Dapat dilihat bahwa koefisien yang diperoleh bernilai positif, jadi apabila terjadi peningkatan pada $\left(\mathrm{X}_{3}\right)$, maka $\mathrm{Y}$ akan meningkat dan sebaliknya.

Hasil perhitungan menunjukkan nilai Koefisien Determinasi $\left(R^{2}\right)$ sebesar 0,313 . Hasil tersebut menjelaskan bahwa variabel arus kas bebas, hutang dan laba yang disertakan dalam persamaan regresi terhadap $\mathrm{Y}$, adalah sebesar $31,3 \%$ dan sisanya dipengaruhi oleh variabel lain yang tidak dimasukkan dalam persamaan ini.

Hasil dari uji normalitas dengan menggunakan P-P Plot of Regression Standarization Residual menunjukkan semua data variabel arus kas bebas, hutang, laba dan dividen telah berdistribusi normal karena masingmasing variabel memiliki nilai signifikansi yang dilihat pada OneSample Kolmogorov-Sminorv Test (Asymp. Sig. (2-tailed)) lebih besar dari $\alpha(0,05)$.

Hasil dari uji multikolinearitas, menyatakan bahwa VIF dari variabel arus kas bebas sebesar 1,075, variabel hutang sebesar 1,050 dan variabel laba sebesar 1,044, maka variabel independen lebih kecil dari 10, dimana sehingga tidak terjadi multikolinearitas.

Hasil uji heteroskedestisitas dilihat pada hasil scatterplot terlihat titik-titik tersebar (tak berpola) baik di atas maupun di bawah angka 0 pada sumbu Y, sehingga disimpulkan ragam residual homogen (asumsi terpenuhi).

Hasil dari uji autokorelasi menunjukkan bahwa tidak ada autokorelasi positif maupun negatif, karena hasil dari Durbin-Watson menunjukkan angka sebesar 1,207 yang berarti hasil tersebut berada dalam range angka yang termasuk dalam kategori tidak ada autokorelasi yaitu -2 sampai +2

Pengujian Hipotesis I dalam penelitian ini menggunakan uji $\mathrm{F}$ dan uji t.Hasil uji $\mathrm{F}$ dari analisis regresi linier berganda dengan menggunakan $\mathrm{d} f_{1}=3$ dan $\mathrm{d} f_{2}=63$ pada variabel signifikansi sebesar 5\% atau 0,05 diperoleh $F_{\text {tabel }}$ sebesar 2,75 sedangkan $F_{\text {hitung }}$ sebesar 8,975 , karena $F_{\text {hitung }}$ lebih besar dari pada $F_{\text {tabel }}$ dan memiliki signifikansi 
lebih kecil dari 0,05 yaitu sebesar 0,000, sehingga $\mathrm{H}_{0}$ ditolak dan $\mathrm{H}_{\mathrm{a}}$ diterima, yang berarti variabel arus kas bebas $\left(\mathrm{X}_{1}\right)$, hutang $\left(\mathrm{X}_{2}\right)$ dan laba $\left(\mathrm{X}_{3}\right)$ berpengaruh secara simultan (bersamasama) terhadap Dividen.

Hasil Uji t menunjukkan bahwa nilai $t_{\text {hitung }}$ arus kas bebas sebesar 1,407 dan $t_{\text {tabel }}$ sebesar 2,000, karena nilai $t_{\text {hitung }}<t_{\text {tabel }}$ dapat dapat disimpulkan bahwa variabel arus kas bebas $\left(\mathrm{X}_{1}\right)$ berpengaruh tidak signifikan terhadap variabel dividen (Y). Nilai

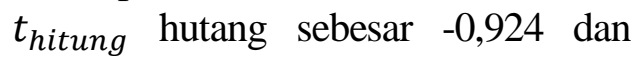
$t_{\text {tabel }}$ sebesar 2,000, karena nilai $t_{\text {hitung }}<t_{\text {tabel }}$ dapat dapat disimpulkan bahwa variabel hutang $\left(\mathrm{X}_{2}\right)$ berpengaruh tidak signifikan terhadap variabel dividen (Y). Sedangkan nilai $t_{\text {hitung }}$ laba sebesar 4,679 dengan $t_{\text {tabel }}$ sebesar 2,000, karena nilai $t_{\text {hitung }}>t_{\text {tabel }}$ dapat disimpulkan bahwa variabel laba $\left(\mathrm{X}_{3}\right)$ berpengaruh signifikan terhadap variabel dividen (Y).

Pengujian Hipotesis II, menyatakan bahwa variabel Laba $\left(\mathrm{X}_{3}\right)$ yang paling berpengaruh terhadap dividen pada perusahaan manufaktur, dengan cara melihat hasil dari nilai koefisien regresi yang terbesar. Hal ini dibuktikan dengan nilai koefisien regresi laba $\left(\mathrm{X}_{3}\right)$ sebesar 1,156, maka hipotesis kedua diterima.

Pembahasan hasil penelitian ini menjelaskan pengaruh variabel arus kas bebas, hutang dan laba terhadap dividen.Pengaruh variabel arus kas bebas terhadap dividen, hasil pengujian regresi linear berganda dengan menggunakan SPSS (Statistical Product and Service Solution) 21, menunjukkan bahwa variabel $\mathrm{X}_{1}$ (Arus Kas Bebas) berpengaruh tidak signifikan terhadap variabel Y (Dividen).

Hasil penelitian ini sesuai dengan teori yang dikemukakan oleh (Brigham dan Houston, 2012:109) bahwa arus kas bebas mempunyai pengaruh terhadap dividen.

Penelitian ini sesuai dengan penelitian terdahulu yang dilakukan oleh (Aeni, 2012) bahwa Free Cash Flow berpengaruh secara tidak signifikan terhadap tingkat pembayaran dividen.

Terdapatnya pengaruh yang tidak signifikan antara arus kas bebas dengan dividen pada penelitian ini dapat disebabkan karena besarnya dividen yang akan dibayarkan sangat dipengaruhi oleh besarnya posisi kas pada suatu perusahaan. Kadang posisi kas yang besar dipandang sebagai suatu keunggulan, namun bagi investor hal tersebut bisa saja dianggap sinyal buruk karena perusahaan tidak dapat memanfaatkan kas dengan maksimal yang berakibat kecilnya return dan berdampak pada pembagian dividen.

Pengaruh hutang terhadap dividen, hasil pengujian regresi linear berganda dengan menggunakan SPSS (Statistical Product and Service Solution) 21, menunjukkan bahwa variabel $\mathrm{X}_{2}$ (Hutang) bepengaruh tidak signifikan terhadap variabel $\mathrm{Y}$ (Dividen).

Hasil penelitian ini sesuai dengan teori yang dikemukakan oleh (Kieso, 2002:362) bahwa peningkatan hutang akan mempengaruhi besar kecilnya laba bersih bagi pemegang saham termasuk dividen yang akan diterima, semakin tinggi hutang maka kemampuan perusahaan untuk membagikan dividen kepada pemegang saham akan semakin kecil. 
Pengaruh laba terhadap dividen, hasil pengujian regresi linear berganda dengan menggunakan SPSS (Statistical Product and Service Solution) 21, menunjukkan bahwa variabel $\mathrm{X}_{3}$ (Laba) berpengaruh positif signifikan terhadap variabel Y (Dividen).

Hasil penelitian ini sesuai dengan teori yang dikemukakan oleh (Santoso, 2009:228) bahwa jumlah laba suatu periode yang tersedia untuk setiap lembar saham biasa yang beredar selama periode tertentu, oleh karena itu dapat dikatakan bahwa Earning per Share yang tinggi tentu perusahaan akan membagikan dividen yang tinggi pula. Semakin tinggi nilai Earning per Share semakin tinggi pula laba yang didapat oleh para pemegang saham dari setiap lembar saham yang dimilikinya.

Penelitian ini sesuai dengan peneliti terdahulu yang dilakukan oleh (Bagus, 2014), bahwa Earning per Share berpengaruh signifikan terhadap Divided Payout Ratio. Perusahaan yang memiliki laba tinggi atau stabil cenderung akan membagikan dividen dengan jumlah yang besar berbeda dengan perusahaan yang memiliki laba yang berfluktuasi atau rendah, maka perusahaan cenderung akan membagikan dividen dengan jumlah yang lebih rendah.

$$
\text { Variabel yang paling }
$$

berpengaruh terhadap dividen. Hasil analisis regresi menunjukkan bahwa variabel yang paling berpengaruh terhadap dividen dilihat dari koefisien regresi yang terbesar adalah variabel laba. Hasil penelitian ini sesuai dengan teori yang dikemukakan oleh (Santoso, 2009:228) bahwa jumlah laba suatu periode yang tersedia untuk setiap lembar saham biasa yang beredar selama periode tertentu, oleh karena itu dapat dikatakan bahwa Earning per Share yang tinggi tentu perusahaan akan membagikan dividen yang tinggi pula. Semakin tinggi nilai Earning per Share semakin tinggi pula laba yang didapat oleh para pemegang saham dari setiap lembar saham yang dimilikinya.

Penelitian ini sesuai dengan peneliti terdahulu yang dilakukan oleh (Bagus, 2014), bahwa Earning per Share berpengaruh signifikan terhadap Divided Payout Ratio. Perusahaan yang memiliki laba tinggi atau stabil cenderung akan membagikan dividen dengan jumlah yang besar berbeda dengan perusahaan yang memiliki laba yang berfluktuasi atau rendah, maka perusahaan cenderung akan membagikan dividen dengan jumlah yang lebih rendah.

\section{SIMPULAN}

Berdasarkan hasil penelitian dan pembahasan yang dijelaskan pada bab sebelumnya, maka dapat diambil kesimpulan bahwa: 1). Variabel Arus Kas Bebas, Hutang dan Laba berpengaruh signifikan terhadap Dividen yang diperkuat dengan Uji $F$ dan Uji t. Hasil Uji F (simultan) menunjukkan bahwa ketiga variabel independen (Arus Kas Bebas, Hutang dan Laba) secara bersama-sama mempengaruhi dividen secara signifikan pada perusahaan manufaktur yang terdaftar di Bursa Efek Indonesia tahun 2012-2014. Hasil Uji t (parsial) dapat dinyatakan bahwa variabel arus kas bebas berpengaruh positif tidak signifikan terhadap dividen. Variabel hutang berpengaruh negatif tidak signifikan terhadap dividen dan variabel laba berpengaruh positif signifikan terhadap dividen. 2). 
Variabel yang paling berpengaruh terhadap dividen adalah variabel laba.

Bagi pihak perusahaansebaiknya sebelum menetapkan pembayaran dividen terlebih dahulu memperhatikan arus kas bebas atau posisi kas bagi pemegang saham, hutang dan laba yang dimiliki, khususnya laba yang dihasilkan oleh perusahaan, karena laba terbukti mempunyai pengaruh terhadap pembayaran dividen dan dapat digunakan untuk mengurangi konflik keagenan yang terjadi di dalam perusahaan.

Bagi investor di pasar modal hendaknya memperhatikan indikatorindikator lain yang dapat mempengaruhi investasi. Hasil penelitian ini menunjukkan bahwa variabel laba berpengaruh terhadap dividen, oleh karena itu laba dapat dijadikan acuan untuk melihat apakah perusahaan bisa membayarkan dividen dengan jumlah yang tinggi atau sebaliknya.

Bagi Peneliti selanjutnya diharapkan untuk memperhatikan faktor-faktor lain. Penelitian lebih lanjut dapat menggunakan sampel dan sektor industri lain atau membandingkan kondisi sebelum dan sesudah inflasi. Hendaknya pada penelitian yang akan datang dapat mengembangkan variabel-variabel lain yang mempengaruhi pembayaran dividen.

\section{DAFTAR PUSTAKA}

Aeni. 2012. "Pengaruh Free Cash Flow, Profitabilitas dan Hutang terhadap Dividend Payout Ratio dengan Menggunakan Regresi Berganda". Skripsi Fakultas Ekonomi dan Bisnis Universitas Muhammadiyah, Malang.

Arthur J. Keown, David F. Scott, Jr, John D. Martin, J. William Petty. 2000. Dasar-Dasar Manajemen
Keuangan. Edisi 1, Penerbit Salemba Empat, Jakarta.

Bagus Tri. 2014. "Pengaruh Net Profit Margin, Earning Per Share, Return on Asset dan Return on Equity terhadap Kebijakan Dividen dengan menggunakan Regresi Berganda". Skripsi Fakultas Ekonomi Universitas Nusantara PGRI, Kediri.

Brigham dan Houston. 2012. DasarDasar Manajemen Keuangan. Buku 1. Edisi 11. Jakarta: Salemba Empat.

2012. Dasar-

Dasar Manajemen Keuangan.

Buku 2. Edisi 11. Jakarta: Salemba Empat.

Darmawan, Deni. 2013. Metode Penelitian Kuantitatif. Bandung: PT. Remaja Rosdakarya

Djumahir. 2009. Pengaruh Biaya Agensi, Tahap Daur Hidup Perusahaan, dan Regulasi terhadap Kebijakan Dividen pada Perusahaan Manufaktur di Bursa Efek Indonesia. Universitas Brawijaya, Malang.

Eva Rahmawati. 2011. "Pengaruh Current Ratio, ROA, Kebijakan Hutang dan Ukuran Perusahaan terhadap Kebijakan Dividen dengan Menggunakan Regresi Logistik". Skripsi Fakultas Ekonomi dan Bisnis Universitas Islam Negeri Syarif Hidayatullah, Jakarta.

Fandy Farid. 2013. "Analisis Pengaruh Free Cash Flow, Kebijakan Hutang dan Pertumbuhan Laba terhadap Kebijakan Dividen dengan menggunakan Regresi Linier Berganda". Skripsi Fakultas Ekonomi dan Bisnis Universitas Brawijaya, Malang. 
Gatot. 2012. Analisis Pengaruh Free

Cash Flow, Profitabilitas, Likuiditas, Leverage dan Earning Per Share terhadap Kebijakan Dividen dengan Menggunakan Regresi Linier Berganda. Universitas Dian Nuswantoro, Semarang.

Ghazali, Imam. 2013. Aplikasi Analisis Multivariate dengan Program IBM SPSS 21 Update Pls Regresi. Semarang: Undip.

Gitman J. Lawrence. 2000. Principle of Managerial Finance. Ninth Edition. Massachusetts: AddisonWesley Publishing Company

Kieso E. Donald, Weygant J. Jerry, Warfield D. Terry. 2002. Akuntansi Intermediate. Jilid 2. Jakarta: Erlangga.

Lucyanda dan Lyliana. 2012. Pengaruh Free Cash Flow dan struktur kepemilikan terhadap Divident Payout Ratio. Jurnal Akuntansi. Vol. 1. No. 2. Pp. 129-138.

Rialdi, 2014. Pengaruh Profitabilitas, Likuiditas dan Leverage terhadap Dividend Pyout Ratio
padaPerusahaan Manufaktur. Skripsi Fakultas Ekonomi Universitas Widyatama, Bandung.

Ross et al. 2009. Pengantar Keuangan Perusahaan (Corporate Finance

Fundamental). Buku 2. Edisi 8. Jakarta: Salemba Empat.

Rosdini. 2009. Pengaruh Free Cash Flow terhadap Dividend Payout Ratio. Working Paper in Accounting and Finance.

Santoso, Iman. 2009. Akuntansi Keuangan Menengah, Buku 2. Bandung: PT. Refika Aditama.

Suhadak dan Ari. 2011. Pemikiran Kebijakan Manajemen Keuangan. Malang: CV. Okani Bukaka.

Sutrisno. 2001. Analisis Faktor-faktor yang Mempengaruhi Dividend Payout Ratio. TEMA. Vol. 2 No. 1.

Weston, Copeland E. Thomas. 2010. Manajemen Keuangan. Jilid 2. Jakarta: Erlangga.

www.idx.co.id 